\title{
Medicine management in districts and primary health care centres (PHC) in the national health insurance (JKN) programme
}

\author{
Raharni, Rini Sasanti, Yuyun Yuniar \\ Center for Resources and Health Services, National Institute of Health Research and Development, Ministry of Health, Indonesia
}

\section{Keywords}

e-procurement

Medicine management

National health insurance (JKN)

Primary health care

\section{Correspondence}

Raharni

Center for Resources and Health Services

National Institute of Health Research and Development Ministry of Health

Indonesia

raharnis@yahoo.com

\begin{abstract}
Aim: This study aimed to identify medicine management in district health offices and primary health care centres (PHCs) after the national health insurance (JKN) programme implementation. Methods: A cross-sectional study was carried out by collecting documents related to medication management and in-depth interviews with the head of the PHC officials and JKN medicine management officers at the PHC in four provinces of Indonesia. Results: The results showed no regional policies related to medicine management; all policies were based on central policies. Medicine management in districts follows the procurement planning suggested by PHCs, which relies on disease patterns. Medicine procurement at PHCs is done by e-purchasing using an e-catalog. Medicines above IDR 200 million are purchased through catalogs provided by the procurement service unit (ULP), and those under IDR 200 million are obtained through a direct appointment. Conclusion: The storage of medicine requires more space and air humidity controlling. The reporting and monitoring of medications e-logistic system are based on 20 indicators and have not been carried out regularly. It is necessary to improve reporting and monitoring systems.
\end{abstract}

\section{Introduction}

The national health insurance (JKN) programme has been implemented in Indonesia since 2014, where the Social Security Administrator for Health (BPJS Kesehatan) is the appointed administering body, part of other national administering bodies. The national social security system is a procedure for administering social security programmes by several social security administering bodies (Law of the Republic of Indonesia Number 40 of 2004 Concerning the National Social Security System, 2004).

In this context, Primary Health Care centres (PHC), known as Puskesmas, are considered the main gatekeepers of the public primary health care system. Notwithstanding PHC, other private primary health care facilities should offer to cooperate with BPJS
Kesehatan. PHC is a health service facility that makes public health and first-level individual health efforts, prioritizing promotion and prevention $(\mathrm{MOH}, 2019)$. It plays an optimal role as a gatekeeper in health services and is required to provide services for 144 diagnoses that should not be referred to the hospitals (Kedokteran, 2012).

Medicine is a substance or combination of active ingredients, including biological products, used to diagnose, prevent, cure, and improve human health (Law of the Republic of Indonesia, 2009).

The pharmaceutical and medical devices system is one of the sub-systems of the national health programme, aimed to ensure safety, efficacy, and quality aspects of pharmaceutical preparations, medical devices, and food, in addition to their availability and affordability (Indonesia, 2012). The implementation of the JKN 
programme brings changes to the health system, including the pharmaceutical aspect. The ability to treat 144 diagnoses cannot be achieved unless necessary medicines are made available in PHCs.

Presidential Decree No.32 of the year 2014, concerning management and utilisation of JKN capitation funds, enacts the capitation fund to be directly transferred to the accounts of PHCs. However, if the status of the PHC does not allow it to have an account, then the capitation fund is transferred to the official district account before it is relayed to the PHC. As a result, PHCs should manage the fund according to the regulation stating that at least $60 \%$ of the amount should be allocated for health services costs and the remaining $40 \%$ for operational expenses, including medicines procurement. The changing in financing scheme has also changed the medicines procurement pattern, where PHCs own funds allow them to afford necessary medicines (Management of FKTP Capitation Funds, 2014).

Once the capitation funds are transferred, PHCs are authorised to manage it. However, appropriate competencies are needed to manage these funds appropriately. For example, the treasurers must have been trained to become familiar with the use of capitation funds. Additionally, there must be a certified procurement officer to procure drugs through e-purchasing (Ministry of Health, 2014).

Despite being authorised to procure medicines, PHCs still rely heavily on the district health office as the source of essential medicines. The situation is prolonged by the installation of a District Pharmacy at the District/City Health Office that procures medicines for all PHCs under their regional authority through large-scale e-purchasing.

E-Catalog is an electronic system that provides information about products, including lists, types, specifications technical, domestic component level (TKDN), domestic products, Indonesian National Standard (SNI), green industrial products, country of origin, price, provider, and other information related to goods/services (LKPP, 2018).

There is a need to find out how district health offices and PHCs procure medicines, considering the availability of capitation funds. The purpose of this study is to explore the management process of drugs in district health offices and primary health care systems from planning to provision, storage, monitoring, and evaluation. The availability and utilization of several indicators are also portrayed to get a comprehensive perspective of the pharmaceutical and medical devices aspects resulting from the JKN programme.

\section{Methods}

This cross-sectional study was carried out in four provinces of Indonesia (Yogyakarta, Bali, East Kalimantan, and East Nusa Tenggara (NTT) provinces), using a qualitative approach with in-depth interviews to determine the management of medicine in health centres. The regions chosen were considered to represent geographical patterns and population density associated with the capitation of PHCs.

The research samples to obtain secondary data (medicine management documents) consisted of 8 medicine managers of the District Pharmacy/City Health Offices and 16 medicine managers of Puskesmas from the four provinces selected, considering the status of BLUD and non-BLUD PHCs. The data collected consisted of documents related to medicine management at the PHCs, including planning, procurement, storage, monitoring, and evaluation.

Additionally, in-depth interviews were held with the Heads of the district pharmacy/city health office and the heads of PHCs, totalling 16 respondents. The whole conversation was recorded after getting permission from the participants.

\section{Ethical approval}

The Health Research Ethics Commission (KEPK), National Institute of Health Research and Development, Ministry of Health, Republic Indonesia, reviewed and granted this study ethics clearance (Number LB.02.01/5.2/KE.357/2016). Informed consent was obtained from all respondents prior to participation in the interview.

\section{Results}

Table I presents the respondents and their distribution per institution and province. The results show there is no regional policy related to medication management. The JKN programme policies related to drug management are dynamic, so regions need strong efforts to adjust to developments in drug management policies. Besides appropriate and dynamic policy objectives, laws were not enforced. For example, no sanctions were taken against suppliers regarding the late delivery of medicines to the region (Hermansyah et al., 2018). 
Table I: Characteristics of respondent

\begin{tabular}{|c|c|c|c|c|}
\hline $\begin{array}{l}\text { Respondents } \\
\text { characteristics (n:10) }\end{array}$ & DIY & Bali & $\begin{array}{l}\text { East } \\
\text { Kalimantan }\end{array}$ & $\begin{array}{l}\text { East } \\
\text { NTT }\end{array}$ \\
\hline $\begin{array}{l}\text { Head of Pharmacy } \\
\text { Institutions in the District / } \\
\text { City Health }\end{array}$ & 2 & 2 & 2 & 2 \\
\hline $\begin{array}{l}\text { Managers in pharmacy } \\
\text { installations in district / } \\
\text { city health offices }\end{array}$ & 2 & 2 & 2 & 2 \\
\hline Medicine managers at $\mathrm{PHC}$ & 4 & 4 & 4 & 4 \\
\hline Head of PHC & 2 & 2 & 2 & 2 \\
\hline
\end{tabular}

In the four provinces, the policy was not implemented optimally, and the only existing regional regulation was related to capitation services. Medicine management in PHCs includes a plan for medication needs, prepared based on needs and disease patterns. JKN medicine procurement in $\mathrm{PHC}$ was done with capitation funds, but in the four provinces, it was also sourced from central funds (known as DAK funds) to cover JKN drug shortages (see Table II)

Table II: Medicine management in districts and primary health care (PHC)

\begin{tabular}{l} 
Districts (Province) \\
\hline Policy \\
The Governor's policy regarding the JKN programme is Universal \\
Health Insurance. Prov: Governor's Policy: JKBM / Balimandra. \\
(integration into JKN). Prov: There is no specific regional \\
regulation on medicine management in the implementation of \\
JKN. Prov: There is no specific Regional Regulation on Medicine \\
management for the Implementation of JKN, referring to the \\
central policy "One gate Policy" with an integrated planning team
\end{tabular}
Districts (Regency/ City) Primary Health care (PHC)

\author{
Financing \\ Costs from DAK APBD I (Buffer). Financing from DAK and central \\ buffer assistance
}

Medicine management refers to the Central Policy (one gate policy) by forming an Integrated Planning Team. There are no specific regulations on medicine management.

\section{Planning}

Based on the needs plan submitted by the district and the drug programme. Programme drug planning is carried out by the programme manager based on stock reports sent by the warehouse and programme requirements data.

Procurement

Provinces, procurement for buffers, procurement of programme medicine based on recommendations from programme holders, are requested to the central government-procurement mechanism for e-catalogue medicine to PPTK (Technical Implementation Officer) and KPA, procurement.

\section{Storage}

Drug storage and distribution to districts/cities as a drug buffer

\section{Reporting}

Drug availability reporting: software (e-logistics). Reports on the availability of medicine and vaccines for 20 indicator medicine. There is still a manual reporting system.
Funds for drug purchases from DAK, APBD II, and APBD I.
Referring to central and regional policies
District/city planning for medicine and health supplies based on the needs of the PHC based on the pattern of disease.

Drug Procurement by the Health Office,

Drug e-catalogue and non-ecatalogue submitted to PPK. None-catalog $<200$ million through direct appointment (PL).

Procurement of non-e-catalogue medicine $>200$ million through auction to PPK (ULP)

Medicines received by the recipient team are stored at the UPT Pharmacy. Drug Programme from the Central to the Province dropped to the district. Drug Storage with FIFO and FEFO systems

Reporting the availability of medicine using software (elogistics). Reports on the availability of medicine and vaccines for 20 indicator medicine are sent directly to the centre, namely to the Ministry of Health. For the drug programme, by each programme manager.
PHC source of drug costs from APBD and JKN capitation ( $7 \%$ from $40 \%$ capitation)

Drug planning based on disease patterns is proposed to the district from the APBD source.

Drug Procurement with capitation by PPK. Puskesmas where there is no procurement official yet, Puskesmas drug procurement is coordinated by the District / City Health Office

\section{Drug Storage with FIFO and FEFO} systems

\section{Drug reporting to District / City Health Office, Reporting}

summarised according to the health needs of the PHC in the city/regency area. Requests and procurement of JKN medicines were carried out by the city/district

health office. JKN medicine procurement by
In the Yogyakarta Province, planning medicine in PHC was based on needs and disease patterns (ten major diseases). The PHC drug needs planning would then be reported to the district/city health office, to be 
district/city health offices was done, considering the limited personnel who must meet the competence and certified procurement officials. The PHC was monitored by the district/city health office and other technical staff, not specifically for medicine management, at a frequency of three to four times a year. The monitoring showed the need to increase the frequency of money transfers from the Central Government and monitoring and evaluation from the provincial health office or the district/city health office. Some unavailable medicines are amlodipine, diazepam $5 \mathrm{mg}$, haloperidol, chloramphenicol, paracetamol $100 \mathrm{mg}$, amitriptyline 25 $\mathrm{mg}$, acyclovir 5\%, metoclopramide $10 \mathrm{mg}$, and propranolol $100 \mathrm{mg}$.

Bali province had never had a drug vacuum from planning, but with the e-catalogue, medicines were not always found although money was available; sometimes, their expiry date was too short. The medicines for JKN PHC must also be purchased through an e-catalogue. Medicines outside the procurement catalogue are procured through a direct nominal valuation mechanism when $<200$ million and those $>\mathbf{2 0 0}$ million are bought through ULP. Drug storage and distribution in the PHC are based on First in First Out (FIFO) and First Expired First Out (FEFO) procedures, where storage conditions of medicines in the PHC storage do not meet space and humidity requirements. Reporting system and logistical monitoring and evaluation are only for 20 items of indicator medicine. Monitoring and evaluation of the $\mathrm{PHC}$ by the DHO has not been organised due to budget constraints. Drug shortages include glimepiride $1 \mathrm{mg}$, simvastatin, vitamin B complex, salbutamol, ambroxol, and paracetamol.

The distribution of medicines to the PHC is shown in Figure 1. In East Nusa Tenggara Province (NTT), PHC drug planning and drug programmes had special meetings, and the planning was based on the calculation of the remaining stock and usage from the year before. The meeting was held at the end of the year. The planning calculates 12-month needs. Drug procurement by the PHC refers to the national formulary, using the ecatalogue for health centres that have procurement officials. However, the obstacles encountered were that JKN medicines ordered in the first trimester often came late. Pharmacists or certified procurement personnel were still lacking, while for the expenditure process from capitation funds, there were rules that must be met, including certified procurement officials. Medicine management sources of funds from the BPJS had not fully funded medicines. In addition to getting JKN medicines with capitation funds, the PHC also received medicines from the district/city health office sourced from DAK funds. Accredited PHCs already had a medicine management SOP, contrary to those not accredited. Drug planning in the PHC was based on the needs and disease patterns in the regions. The distribution to subPHCs called pustu and poskesdes was carried out by the $\mathrm{PHC}$ drug manager. Obstacles or constraints in medicine management in JKN implementation include drug requests that sometimes could not be fulfilled. Unavailable medicines included dental products, amlodipine, and oxytetracycline.

In East Kalimantan province, programme drug requests from PHCs to programme holders are forwarded to the pharmacy section. For JKN drug procurement, although funds are available, medicines lack in the PHC and the district/city pharmacy warehouse due to an Extraordinary Event (KLB) or a distribution gap. The vehicle at the $\mathrm{PHC}$ is an ambulance. The storage method is the FEFO system with special conditions: when the drug is delivered, it must have a 24-month expiry date; those that expire before 24 months must have a certificate from the factory. Unavailable medicines include metformin, simvastatin, mefenamic acid, Glyceryl Guaiacolate (GG), CTM, ambroxol, and ethyl chloride for teeth.

\section{Discussion}

This study results indicate that the drug policy in the four provinces has not been implemented optimally, and the only existing regional regulation was related to capitation services. Medicine management refers to the Central Policy (one gate policy) by forming an Integrated Planning Team. Medicine management in PHCs includes a plan for medication needs, prepared based on needs and disease patterns. According to Raharni, government policies related to medicines management in the JKN era began with the national medicines policy, taking into account the benefits of medicines in JKN, both in terms of accessibility and affordability, with rational using of medicine (Raharni et al., 2018). This finding seems to be consistent with the report, drug planning by method consumption and morbidity. The results indicated that the planning and procurement process were not appropriately applied. In the planning process, compliance with the national formulary was still lacking; changes in disease prevalence affected the accuracy of drug planning. (Aisah et al., 2020). The planning and distribution of medicines had not been following the standards fully, with some indicators not meeting the standards, i.e., the accuracy of planning, planning irregularities, and drug availability (Boku et al., 2019). The study reports that the drug requirement plan is calculated according to the average use of medicine, safety stock, lead time, and remaining stock. Lead time in Kediri Regency is based on the length of procurement process time up to drug reception; since it takes three months, the lead count time is three times the average usage (Sulistyorini, 2016). 


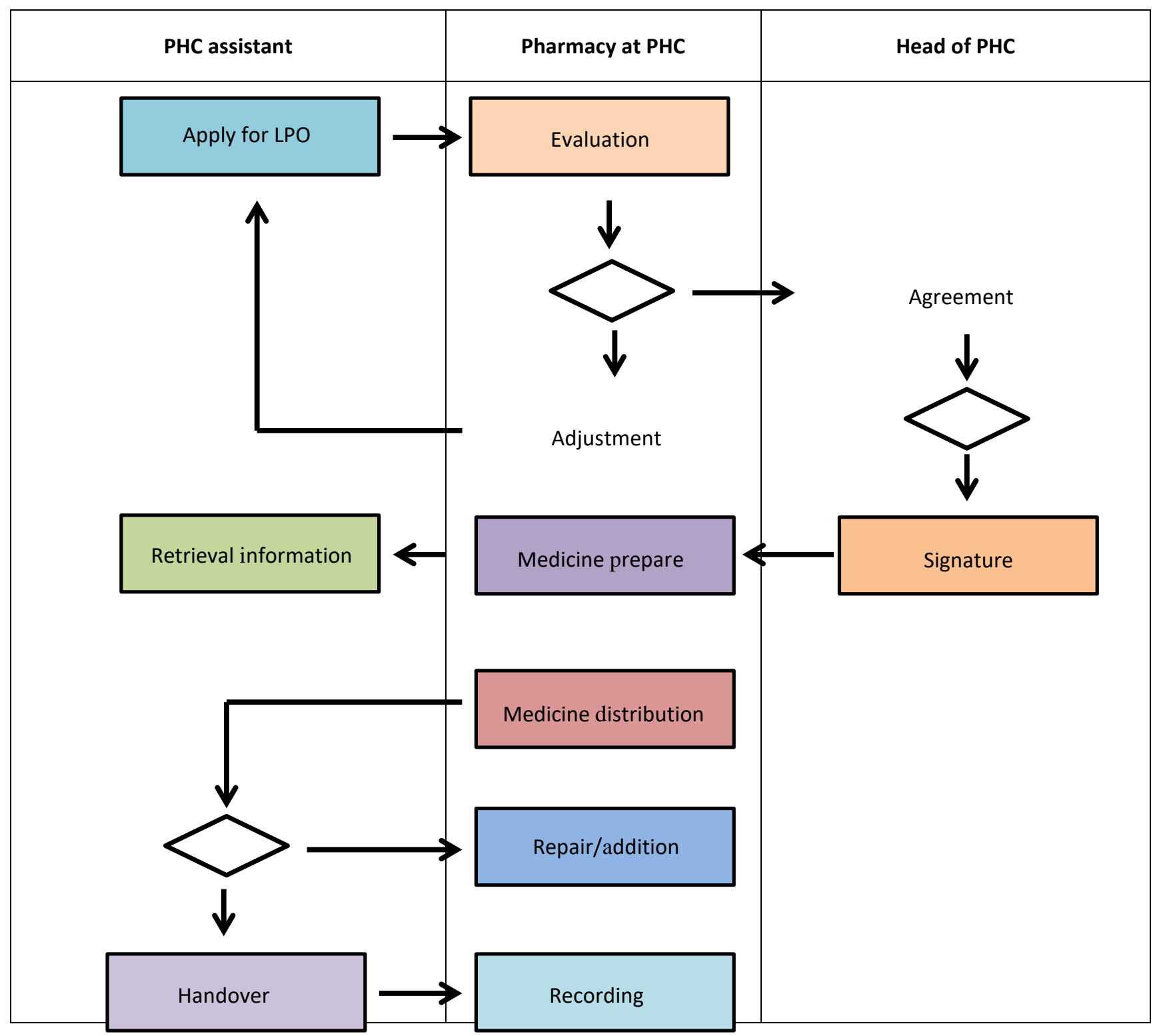

Figure 1: Drug distribution at PHC

In districts, drug procurement by the Health Office, drug e-catalogue, and non-e-catalogue are submitted to PPK. Non-e-catalogue medicines $<200$ million are bought through direct appointment $(\mathrm{PL})$, while non-ecatalogue medicines $>200$ million are purchased by auction to PPK (ULP). This finding seems to be consistent with the report, drug procurement with e-purchasing, which is the most valuable IDR 200,000,000. Direct Procurement of Goods/Construction Work is the selection method to get Goods Providers/Construction Work/ Other Services, which is worth a maximum of IDR 200,000,000 (Presiden, 2018).

In provinces and districts, medicines received by the recipient team are stored at the installation pharmacy, using FIFO and FEFO storing systems. In PHCs, medicine storage also uses the FIFO and FEFO systems. This result seems to be consistent with previous findings showing that the storage process does not use the alphabetical system and the absence of a special cabinet for the medicine class of narcotics. In addition to this system, drug storage space is not sufficient to accommodate the stock of medicines, causing excessive accumulation of boxes due to inadequate facilities and infrastructure, such as shelves, trolleys, and human resources in the process of medicine management (Astriani, 2018). Drug procurement/demand at the PHC is in accordance with applicable regulations. Drug storage at PHC used the FEFO and FIFO methods (Indriawan et al., 2014). The features that did not meet the standards were 
selection, planning, procurement, percentage of available fund allocation (10,98\%), and distribution (Oktaviani et al., 2018). The medicine management system at the Pharmacy Warehouse of the Ngawi District Health Office was adequate, while shortages are often caused by empty stocks by PBF. (Hapsari, 2019)

The result showed that medicine management had not been fully in accordance with the standards. Of the seven measured indicators, one of them met the standard, namely, the percentage of the available fund compared with the cost planned. The other six indicators that did not comply with the standards were percentage of drug procurement with fund allocation, percentage of drug item planned, percentage of total quantities of an item, procurement frequency of each drug, frequency of uncompleted contract, frequency of delayed rate in payment by the hospital (Ulfah et al., 2018).

Drugs are stored in pharmaceutical warehouses, some still not stored alphabetically. As for drug distribution, the frequency of once every two months is in accordance with the proposed request in the LPLPO; however, the drug distribution process is done by pick a ball from Medical Health Care to Health Department. (Lubis, 2017)

Some of the required activities cannot be implemented, and the lack of human resources results in the placement of health workers who do not comply with the required level of education. Based on this result, it can be concluded that the management of medicine in Danowudu Public Health Center needs to be implemented according to the regulation of pharmaceutical service standards in the PHC (Mailoor et al., 2019).

The results showed that the drug management planning in the Health Office of West Muna Regency and Pharmacy Warehouse of West Muna Regency was based on epidemiological methods of drug supply, which are adapted to the disease pattern, as suggested, using request sheet and usage sheet. Storage of the medicine in local government clinics is still inadequate, but the storage has fulfilled the standards. The distribution of medicines has been appropriate with the procedure of management and eliminated the expired medicines (Rismalawati, 2015).

Reports on the availability of medicine and vaccines used 20 drug indicators, including medicines and vaccines that support maternal health, child health, disease prevention, and widely used basic health service medicines comprised in the National Formulary (Directorate of Public Medicine Development, 2015). In some districts, reporting is still manual. This finding seems to be consistent with previous reports, showing that there were 12 health centres $(60.0 \%)$ that had good storage methods, and eight health centres $(40.0 \%)$ were unfavourably rated (Poernomo et al., 2019). Information System Medicine Distribution of Health Center Community in Pharmacy Stockroom of District Banjar consisted of a web-based, user-friendly platform. It covered reception and distribution, usage reports, online requests, data of available medicines and stock (Rismalawati, 2015).

The medicine management system at Kamonji Health Center was in accordance with the Ministry of Health RI No. 74 of 2016. However, there are still obstacles in the management process, such as lack of medications and inadequate drug storage rooms, still requiring supporting facilities for medicine management (Muthahara et al., 2018).

\section{Conclusion}

The results show there is no regional policy related to medication management. The JKN programme policies related to drug management are dynamic, so regions need strong efforts to adjust to developments in drug management policies. In the four provinces, the policy was not implemented optimally, and the only existing regional regulation was related to capitation services. Medicine management in PHCs includes a plan for medication needs, prepared based on needs and disease patterns. JKN medicine procurement in PHCS was done with capitation funds, but in the four provinces, it was also sourced from central funds (known as DAK funds) to cover JKN drug shortages. Technical guidance and budgets in the four provinces are still limited. Finally, storage facilities are not yet in accordance with the humidity requirements, and monitoring and evaluation are not performed periodically.

\section{Acknowledgements}

The author of this paper would like to give high appreciation to the Head of the Center for Resources and Health Services, National Institute of Health Research and Development (NIHRD), the Scientific Advisory Committee for the Center for Resources and Health Services for the Research and Development Agency for providing financial support and guidance. The Central Administration of Health Resources and Services has helped organize the conduct and management of the research. We also thank the Head of the Provincial Health Office, Head of District/ City Health Service, Head of Primary health care, as well as 
to all informants who provided valuable information in this research.

\section{References}

Aisah, N., Satibi, \& Suryawati, S. (2020). Evaluation of Drug Management at the Planning and Procurement Stage at the Pati District Health Office. Majalah Farmaseutik, 16(1), 3442. https://doi.org/10.22146/farmaseutik.v16i1.47972

Astriani, D. (2018). Analysis of Drug Management in the Pharmacy Installation of the Lahat District Health Office in 2018

Boku, Y., Satibi, S., \& Yasin, N. M. (2019). Evaluation of the Planning and Distribution of the Program in the Health Office of Southeast Sulawesi Province. Journal of Management and Pharmacy Practice, 9(2), 88-100. https://doi.org/10.22146/jmpf.42951

Directorate of Public Medicine Development, M. of H. of the R. of I. (2015). Pemantauan Indikator Kinaerja Dit Bina Obat Publik dan Perbekes

Hapsari, R. (2019). Drug evaluation management in the pharmacy warehouse of Ngawi thesis district health office

Hermansyah, A., Sainsbury, E., \& Krass, I. (2018). Multiple policy approaches in improving community pharmacy practice: The case in Indonesia. BMC Health Services Research, 18(1), 1-14. https://doi.org/10.1186/s12913-0183258-8

Indonesia, P. of R. (2012). Presidential Regulation of the Republic of Indonesia No 72 of 2012 concerning the National Health System (Vol. 7, Issue June, pp. 1-25)

Indriawan, I., Wahyudi, W. T., \& Rahayuningsih, A. (2014). Analysis of Drug Management at Gaya Baru V Health Center, Bandar Surabaya District, Central Lampung Regency. Holistik Jurnal Kesehatan, 8(1), 1-6. http://ejurnalmalahayati.ac.id/index.php/holistik/article/vie w/87

Law of the Republic of Indonesia. (2009). Law of the Republic of Indonesia No. 36 of 2009 concerning Health

Lubis, A. S. P. (2017). Analysis of Drug Logistics Management in the Pharmacy Installation of the Deli Serdang Lubuk Pakam District Health Office in 2017. Fakulas Kesehatan Masyarakat Universitas Sumatra Utara

Mailoor, R. J., Maramis, F. R. R., \& Mandagi, C. K. F. (2019). Analysis of Drug Management at Puskesmas Danowudu, Bitung City. Kesmas : National Public Health Journal, 6(3), 114.

http://www.ejournalhealth.com/index.php/kesmas/article/ view/459

Ministry of Health of the Republic of Indonesia. (2014). Peraturan Menkes, RI, No 19 Th 2014, Penggunaan Dana Kapitasi (Vol. 2008)

Muthahara, Sakung, J., \& Andri, M. (2018). Analysis of the Drug Management System at the Kamonji Health Center, West Palu District. 775-782
Oktaviani, N., Pamudji, G., \& Kristanto, Y. (2018). Evaluation of Drug Management in the Pharmacy Installation of the Regional General Hospital of NTB Province in 2017 Drug Management Evaluation in Pharmacy Department of NTB Province Regional Hospital during 2017 Hospital Period is a health institution. 15(2), 135-147

Poernomo, D. H., Girsang, E., Nasution, S. W., \& Ginting, C. N. (2019). Analysis of Factors Related to Drug Storage at the Jambi City Health Center in 2018. Scientia Journal, 8(1), 381389. https://doi.org/10.35141/scj.v8i1.531

Presiden, P. (2018). Regulation, President of the Republic of Indonesia No. 16 of 2018 concerning Government Procurement of Goods / Services

Raharni, R., Supardi, S., \& Sari, I. D. (2018). Kemandirian dan Ketersediaan Obat Era Jaminan Kesehatan Nasional (JKN): Kebijakan, Harga, dan Produksi Obat. Media Penelitian Dan Pengembangan Kesehatan, 28(4), 219-228. https://doi.org/10.22435/mpk.v28i4.269

Rismalawati, L. (2015). Study of Drug Management in Puskesmas Lawa, West Muna District, 2015. 151(september 2016), 10-17

Sulistyorini, A. (2016). Evaluation of Planning and Distribution of Program Drugs at the Health Office of Sulawesi Province Medication Planning Using the Consumption Method at the Health Office of Kediriara Regency. Jurnal Penelitian Kesehatan Suara Forikes, VII(3), 112-120

Ulfah, M., Wiedyaningsih, C., \& Endarti, D. (2018). Evaluation of Drug Management in Planning and Procurement Phase at Muntilan Regional Hospital, Magelang District, 2015 - 2016. Jmpf, $\quad$ 8(1), 24-31. https://journal.ugm.ac.id/jmpf/article/view/31883/pdf 